\title{
Varied Impacts of Globalization on Religion in a Contemporary Society
}

\author{
Asep Muhamad Iqbal \\ Institut Agama Islam Negeri Palangka Raya, Indonesia \\ and Asia Research Centre, Murdoch University, Australia \\ am.iqbal@iain-palangkaraya.ac.id
}

\begin{abstract}
This article discusses the current situation of religion caused by the forces of globalization by analyzing the developing phenomenon related to religion in contemporary society. It argues that globalization has a mixed impact on religion in ways that lead to the opposing view of secularist scholars that religion will be diminished. Apparently, religion has experienced a revival in many parts of the world, mainly in the form of religious fundamentalism. Problems and challenges posed by globalization, such as the environmental crisis and secular society have provided the opportunity and the power to religion to revitalize itself and to transform themselves into a religion with a new form that has a role and a new identity. Furthermore, globalization may lead to the decline of organized religion in modern society and certain intellectual subculture, but it does not cause the death of religion in private life. This is in line with the emergence of the phenomenon of "believing without belonging". In short, globalization has helped to transform the religion itself and changed its strategy to address the problems and challenges of globalization to create "world desecularization".
\end{abstract}

[Artikel ini membahas keadaan mutakhir agama yang diakibatkan oleh kekuatan-kekuatan globalisasi dengan melakukan analisa atas fenomena yang sedang berkembang terkait agama dalam masyarakat kontemporer. Ia berargumen bahwa globalisasi memiliki dampak yang beragam terhadap 
agama dengan cara-cara yang justru mengarah kepada kebalikan dari ramalan musnahnya agama sebagaimana dipromosikan oleh para pendukung teori sekularisme. Tampaknya, agama mengalami kebangkitan kembali di berbagai belahan dunia, utamanya dalam bentuk gerakan fundamentalisme agama. Masalah dan tantangan yang diakibatkan oleh globalisasi, seperti krisis lingkungan dan masyarakat sekuler, justru telah memberikan kesempatan dan kekuatan kepada agama untuk merevitalisasi dirinya dan melakukan transformasi diri menjadi agama dengan bentuk baru yang memiliki peranan dan identitas baru. Lebih jauh, globalisasi telah menyebabkan kemunduran agama formal pada masyarakat modern dan subkultur intelektual tertentu, meski tidak sampai menyebabkan kematian agama dalam kehidupan pribadi. Hal ini seiring munculnya fenomena "believing without belonging". Singkat kata, globalisasi telah membantu agama mentransformasi dirinya dan mengubah strateginya dalam mengatasi berbagai masalah dan tantangan globalisasi sehingga menciptakan "desekularisasi dunia".]

Keywords: globalization, religion, secularization theory, globalization impact.

\section{Introduction}

The discussions of globalization as one of the most powerful social forces of the twentieth century began to bloom in a diverse range of literature in social science in the 1980s. Being fascinated by the nature and consequences of globalization, experts ranging from social scientists to political leaders have tried to understand and explain this global phenomenon. Due to its complex processes and forces of changes and various impacts, they do not express a conclusive definition, nature and impacts of globalization. However, for the purpose of this article, globalization here is defined based on the concept developed Anthony McGrew." Globalization is "the multiplicity of linkage and interconnection that transcend the nation-state which make up the

\footnotetext{
1 Anthony McGrew, "A Global Society?," in Modernity, An Introduction to Modern Societies, eds. Stuart Hall and David Held (Malden: Blackwell Publishing, 2000), 466-503.
} 
modern world system." It refers to "a process through which events, decisions, and activities in one part of the world can come to have significant consequences for individuals and communities in quite distant parts of the globe."3 Moving away from classical sociological idea of society, globalization operates on a global scale across the national boundaries making individuals, societies and organizations in the world interconnected and integrated through communication and transportation technology. This new temporal and spatial features have resulted in the compression of time and space and the overcome of tyranny of distance.

This article explains how globalization has diverse, even paradoxical implications for religion. It is certain that globalization as a global process and phenomenon has significant implications on contemporary societies. Yet, globalization seems to be producing various and contradictory impacts on contemporary society. For example, it produces neither the triumph of 'the global' nor the survival of 'the local', but rather varied and contradictory consequences of both. ${ }^{4}$ It seems that globalization process does not result in a more homogenous world or uniform impacts. Robert Schaeffer concludes:
Globalization does not have uniform consequences or create a more "homogenous" world. Instead, globalization has had diverse consequences that were anticipated in advance...Moreover, the diverse consequences are not uniformly positive or negative but simultaneously good for some and bad for others. ${ }^{5}$

In the words of Roland Robertson, globalization has created diverse impacts or even paradoxical ones for global society. He asserts:

...Globalization thus involves a double and somewhat paradoxical process. Because there is no common and dominant model to which societies can conform, each society creates its own particular image of

\footnotetext{
${ }^{2}$ Ibid., 470.

${ }^{3}$ Ibid.

4 Stuart Hall, "The Question of Cultural Identity," in Modernity, An Introduction to Modern Societies, eds. Stuart Hall and David Held (Malden: Blackwell Publishing, 2000), 632.

${ }^{5}$ Robert Schaeffer as cited in Masamichi Sasaki, "Globalization and National Identity in Japan,” International Journal of Japanese Sociology 13, no. 1 (2004): 72.
} 
global order by promoting, even inventing, its national image of the good society. ${ }^{6}$

The diverse impacts of globalization also apply for cultural identities. According to Hall, there are three possible consequences of globalization on cultural identities. First, identities are "being eroded as a result of the growth of cultural homogenization and the global postmodern." Second, identities are "being strengthened by the resistance to globalization." Third, identities are "declining, but new identities of hybridity are taking their place."7

Applying to religion, one of the most important identities of human society, globalization may have implied on faith in the following three possible impacts. First, religion is being eroded because of extensive and intensive secularization process. Second, religion is being strengthened because of resistance to globalization. Third, religion is declining but it has developed new identities of hybridity.

In the following, this article will examine the current state of religion which resulted from globalization forces by analyzing some recent phenomena concerning religion in contemporary society. It argues that that globalization has diverse impacts on religion in such ways that are contrary to the prediction of the end of religion in modern society promoted by the proponents of secularization theory. In doing so, this article, first, highlights the secularization theory that posits the end of religion in the face of modernization process. Second, it explains the current state of religion in the form of diverse religious responses to the globalizing world. Lastly, the article concludes with some general ideas about the diverse impacts of globalization on religion and their implication for the secularization theory.

6 As cited in Masamichi Sasaki, "Globalization and National Identity in Japan," International Journal of Japanese Sociology 13, no. 1 (2004): 72.

${ }^{7}$ Hall, "The Question of Cultural Identity," 619. 


\section{Secularization Theory: The End of Religion}

In the nineteenth century, some theorists such as Auguste Comte, Emil Durkheim, Ferdinand Tonnies, Max Weber and Karl Marx, whose influential ideas continue to shape today social sciences, concluded that "religion was a declining force in the world." stimulated by modernization forces, religion would become less important factor in human life of modern society and a modern secular system would be a dominant force as theological system was falling down. Furthermore, according to these scholars, religion would eventually vanish from the lives of modern secular society. ${ }^{9}$

These ideas refer to what so-called "secularization theory". The basis of this theory is rooted in the Age of Enlightenment. Voltaire in the eighteenth century remarked that "an age of enlightenment would replace superstition and authoritarian religious order."10 In addition, as Liftin argued, being unsatisfied by religious and theocratic explanations, early social scientists developed basis for a tradition of rational explanations of human behavior. ${ }^{11}$

According to Berger, the core idea of secularization theory is simple: "Modernization necessarily leads to a decline of religion, both in society and the minds of individuals." 12 The death of religion has been predicted by social scientists and western intellectual since three centuries ago. ${ }^{13}$ It was Thomas Woolston in 1710 who first predicted that modernity would triumph over faith and Christianity would come to an end by $1900 .{ }^{14}$ Another prophet of secularization, Auguste Comte, also predicted the death of religion and would be replaced by the science of sociology, but he did not announce when it would happen. He pointed

\footnotetext{
8 Shupe as cited in Jonathan Fox, "Religion as an Overlooked Element of International Relations," International Studies Review 3, no. 3 (2001): 54.

9 Shupe as cited in Fox, "Religion as an Overlooked Element," 55.

10 Appleby as cited in Fox, "Religion as an Overlooked Element," 54.

${ }^{11}$ Liftin as cited in Fox, "Religion as an Overlooked Element," 54.

12 Peter L. Berger, "The Desecularization of the World: A Global Overview," in The Desecularization of the World: Resurgent Religion and World Politics, ed. Peter L. Berger (Washington: Ethics and Public Policy Center, 1999), 2.

13 Rodney Stark, "Secularization, R.I.P.," Sociology of Religion 60, no. 3 (1999): 249-273.

14 Stark, "Secularization, R.I.P.," 249.
} 
out that "as a result of modernization, human society was outgrowing 'theological stage' of social evolution and a new age was dawning in which the science of sociology would replace religion as the basis for moral judgments." ${ }^{\prime 15}$

In the early of the twentieth century, social scientists echoed this secularization theory. A.C. Crawley remarked that "the opinion is everywhere gaining ground that religion is a mere survival from a primitive... age, and its extinction only a matter of time."16 Max Weber asserted that modernization would result in the "disenchantment" of the world and Sigmund Freud convinced his students that religion was the "greatest of all neurotic illusions" that "would die upon the therapist's couch." "17

In the 1950s and 1960s, social scientists believed that the end of religion was underway and ongoing. Political scientists shared a common belief that "modernization would reduce the political significance of primordial phenomena such as ethnicity and religion." "The distinguished anthropologist Anthony Wallace argued that "evolutionary future of religion is extinction" and "it already was well underway in the advanced nations." "Then, Peter Berger in 1968, who withdraw his support for secularization theory in the 1990 s as will be seen below, ${ }^{20}$ was convinced to say that "by the $21^{\text {st }}$ century, religious believers are likely to be found only in a small sects, huddled together to resist a worldwide secular culture." 21

According to Stark, the prophecies of death of religion in secularization thesis suggest the following five things. ${ }^{22}$ First, it is commonly believed that "modernization is causal engine dragging the gods into retirement." Secularization thesis has a strong connection with

\footnotetext{
15 Stark, "Secularization, R.I.P.," 250.

16 As cited in Stark, "Secularization, R.I.P.," 250.

${ }^{17}$ Stark, "Secularization, R.I.P.," 250.

${ }^{18}$ Fox, Religion as an Overlooked Element," 55.

${ }^{19}$ Stark, "Secularization, R.I.P.," 250.

20 Berger, The Desecularization of the World."

${ }^{21}$ Stark, "Secularization, R.I.P.," 250.

22 Stark, "Secularization, R.I.P.," 251-253.
} 
modernization theory; the increase of industrialization, urbanization and rationalization would bring about the decrease of religious faith. Second, secularization theory no only predicted the end of religion in terms of religious institution as expressed in the separation of church and state and the decline of authority of religious leaders, but also in the sphere of individual piety and religiousness. As Thomas Jefferson announced, the Christian beliefs, such as the belief in divinity of Jesus, would be regarded by the individuals in modern society as implausible. Third, it is explicit that science has influenced mostly the death of religion in modern secular society. Comte said that science would free people from "the superstitious fetters of faith". Fourth, secularization is unstoppable social force; once achieved, it is irreversible as it is absorbing state. Fifth, there is a belief among proponents of secularization that secularization process not only applies to Christianity or Christendom, but also to other world religion and global world. It is not only belief in the Christ is "doomed to die out" but also "belief in supernatural powers".

\section{Current State of Religion in the Globalizing World}

As noted above, globalization has affected many aspects of contemporary society in diverse and paradoxical ways and degrees. Religion, as one of the important aspects of contemporary society, has also been affected by globalizing forces in diverse ways resulting in, at least, three different forms of religious responses to globalization as follows.

1. Resurgence of Religion in the Global Society

The aforementioned secularization theory refers to a long-held conviction among the vast majority of Western social theorists that religion is a declining force and eventually will be only an historical memory. Contrary to this prophecy, the world today shows the religion is not dying. According to Berger, secularization theory promoted by historians and social scientists is "essentially mistaken" for global society of world today is "as furiously religious as it ever was, and in some places more so than ever." He argues that, on one hand, modernization has secularizing forces, even more so in some places than in others. But, on 
the other hand, it also has generated counter-secularization movements. It is also certain, he adds, that modernization has caused the loss of power among religious institutions particularly in the Western societies. Yet, in the level of individual lives, religious beliefs and practices have continued to persist. ${ }^{23}$

For Berger, the persistence of religion in global society has to do with the complicated relation between religion and modernity. The relation between these two is not homogenous, one dominates the other. Instead, it is characterized as complicated as shown by two following strategies. ${ }^{24}$

First, religious communities have rejected any modern ideas and values. To do this, religious communities have two strategies. They have taken over society and made a counter modernity movement through religious revolution. This can be seen, among others, in the case of Iranian Revolution in 1979 led by Ayatollah Khomeini. On the other hand, to reject modernity, religious communities have established religious subculture to protect themselves from influences of the outside societies and foreign ideas. The Amish community in eastern Pennsylvania, the US, can be a good example. This is a promising strategy, but too difficult to implement due to powerful force of modernity and globalization. ${ }^{25}$

Second, religious communities and institutions have developed an adaptation strategy. They have taken and to some degree modified modern ideas and values in the light of their own interests. As a result, generally religious communities have survived in the face of secularized world, and even flourished in some places. This can be seen in the most cases of religious stubborn in world today. ${ }^{26}$

In addition, secularization theory has suffered from empirical evidence from the very start. $^{27}$ Commenting on the popularity of

\footnotetext{
${ }^{23}$ Berger, "The Desecularization of the World," 2.

${ }^{24}$ Ibid., 3-4.

25 Ibid.

${ }^{26}$ Ibid., 4.

27 Stark, "Secularization, R.I.P.," 254.
} 
secularization thesis among theorists in nineteenth century, Alexis de Tocqueville noted:

\footnotetext{
Unfortunately, the facts by no means accord with their theory. There are certain population in Europe whose unbelief is only equalled by their ignorance and debasement; while in America, one of the freest and most enlightened nations in the world, the people fulfil with fervor all the outward duties of religion. ${ }^{28}$
}

A study by Finke and Stark shows that religiosity among American people has not decreased ${ }^{29}$ and that by Greely indicates that the rate of church membership has increased dramatically to more than triple than before. $^{30}$

Studies by Michael Winter and Christopher Short refer to the existence of what Grace Davie calls as "believing without belonging". They reveal a high level of subjective religiousness and a relatively low level of secularization in Europe: "What is clear is that most surveys of religious beliefs in northern Europe demonstrate continuing high levels of belief in God and some of the general tenets of the Christian faith but rather low levels of church attendance." 31

Furthermore, statistical data show a high level of religiosity of global society today. A survey of 44 countries by Pew Research Centre in 2002 reveals the importance of religion in people's lives. Surprisingly, religion in the United States of America is regarded as very important by 59 percent of population. Out of ten people in Africa, eight consider religion as very important in their lives. Except in Argentina with only 39 percent, vast majority of people in Latin America share the same view. In Europe, religion still gains popularity among population of the United Kingdom and Poland with 39 percent for both. Asia also witnesses the same trend; population of countries surveyed consider religion as very

\footnotetext{
28 As cited in Stark, "Secularization, R.I.P.," 254.

${ }^{29}$ Finke and Stark as cited in Stark, "Secularization, R.I.P."

${ }^{30}$ Greely as cited in Stark, "Secularization, R.I.P."

${ }^{31}$ Winter and Short as cited in Stark, "Secularization, R.I.P.," 264.
} 
importance: Indonesia 95 percent, India 92 percent, and the Philippines and Bangladesh 88 percent. $^{32}$

In addition, the global society has not witnessed the arrival of scientific atheism. According to Stark, the assumption by the proponents of secularization theory that religion is incompatible with science is "largely fictional". It is interesting to note that scientists are not particularly irreligious as indicated by the fact that the proportion of American academics who consider themselves as religious is high. Compared to anthropologists and psychologists, physical and natural scientists are twice much more to regard themselves as religious persons. ${ }^{33}$ Another study by Edward Larson and Larry Witham found that around $40 \%$ of eminent American scientists selected the option "I believe in God to whom one may pray in the expectation of receiving an answer." This is slightly lower than those who selected another option "I do not believe in God as defined above," who constituted around 45\% of total respondents. Nevertheless, this shows that there has not been a significant decline in belief in God among scientists and subjective religiousness remains high among them. ${ }^{34}$

\section{The Emergence of Religious Fundamentalism}

It is worth noting that current global secular world witnesses the resurgence of conservative-traditionalist religious movements. These movements have been often labelled as "fundamentalism" by media and scholarly publications, though historically the term refers a specific religious movement in American Protestantism, which rejected biblical criticism and the teaching of evolutionism and held biblical literalism and strong patriarchal authority. ${ }^{35}$ In Protestant Christianity, this can be exemplified by the rise of Evangelicalism and Pentecostalism in the

\footnotetext{
32 Desmond Cahill, "God and Globalization: The Role of Faith Communities in Building Social Capital and Constructing Peace," paper prepared for the conference International Perspectives on Peace and Reconciliation, the University of Melbourne (July 2003), 2.

33 Stark, "Secularization, R.I.P.," 264-266.

${ }^{34}$ Edward Larson and Larry Witham as cited in Stark, "Secularization, R.I.P.," 265-266.

35 Martin Riesebrodt, "Fundamentalism and the Resurgence of Religion," Numen 47, no. 3 (2000): 269-170.
} 
United States. ${ }^{36}$ However, Protestantism is not unusual in this phenomenon. There are rapid growing orthodox groups in Judaism, both in Israel and in the Diaspora. ${ }^{37}$ Religious fundamentalism also rises in Hinduism as a response to modernity. ${ }^{38}$ In Russia, the collapse of Soviet Union is followed by the revival of the Orthodox Church. ${ }^{39}$ There has been a similar revival of conservative movements in other major world religions like Islam, ${ }^{40}$ Hinduism and Buddhism, as well as in smaller religious communities such as Shinto in Japan and Sikhism in India.

These religious movements have different theological basis and socio-political implications. But, there is one thing they have in common; they are fully inspired by religious tenets and doctrines. Moreover, operating across national and cultural boundaries, these conservative religious movements are characterized by common features: "great religious passion, a defiance of what others have defined as the Zetgeist, and a return to traditional sources of religious authority" and a rejection of "modernity as defined by progressive intellectuals."

Besides, fundamentalist movements have flourished among those who consider Western modernization, such as secularization and market economy, as threat and catastrophe. ${ }^{42}$ In general, fundamentalist movements are characterized by three essential features. First, they are a religious phenomenon; religious is very essential as ideology, ethos, goals, leadership of fundamentalism are founded and built on religious beliefs and practices. Second, religious fundamentalism is "a reaction to social

36 David Martin, "The Evangelical Upsurge and Its Political Implications," in The Desecularization of the World: Resurgent Religion and World Politics, ed. Peter L. Berger (Washington: Ethics and Public Policy Center, 1999), 37-50.

${ }^{37}$ Jonathan Sack, "Judaism and politics in the modern world," in The Desecularization of the World: Resurgent Religion and World Politics, ed. Peter L. Berger, (Washington: Ethics and Public Policy Center, 1999), 51-64.

38 Robert Hefner, "Multiple Modernities: Christianity, Islam and Hinduism in a Globalizing Age," Annual Review of Anthropology 27 (1998): 83-104.

${ }^{39}$ Berger, "The Desecularization of the World."

40 Abdullahi A. An-Na'im, "Political Islam in National politics and International Relations', in The Desecularization of the World: Resurgent Religion and World Politics, ed. Peter L. Berger (Washington: Ethics and Public Policy Center, 1999), 103-122.

${ }^{41}$ Berger, "The Desecularization of the World," 6-7.

${ }^{42}$ Riesebrodt, "Fundamentalism and the Resurgence of Religion," 282. 
and cultural changes which are experienced as a dramatic crisis" so that it differs from traditionalism. Third, the last, fundamentalist movements are "defensive reaction which attempts to preserve or restore an idealized or imagined former social order which is characterized by a strict patriarchal order and moralism." 43

The emergence of worldwide religious fundamentalism assumes the presence of secularization as it is a reaction against secularizing forces of modernity. It can be explained that modernity undermines certainties and bring about uncertainties. As people cannot bear these uncertainties, any movements, like religious fundamentalism, that are regarded to bring certainties back will gain its market and acceptance. ${ }^{44}$ It is hard to predict the future of this movement. As Berger says, one prediction can be made that fundamentalist movements will find hard to maintain their present religious characteristic and attitude towards modernity without changing strategies. ${ }^{45}$

\section{New Roles and Identities of Religion}

Facing problems and challenges generated by globalization and modernity, religion has developed new roles and identities as their strategies to continue to participate in the globalizing world. In the sphere of international politics, religion has become an important factor and even Samuel Huntington, though it is an exaggeration, regarded it as a source of the clash of civilizations after the end of Cold War era. ${ }^{46}$ The role of religion in international politics can be seen in two kinds of political movements. First, political movements that are truly inspired by religion in their ideology and practices, such as Islamic fundamentalist movements in Egypt and other Muslim countries. Second, political movements that use religion to legitimate their political interests, which are non-religious ones. It is not easy to recognize this type of political movements, but it is not impossible. The good example of this could be the Bosnian conflict

\footnotetext{
43 Ibid., 271-272.

44 Berger, "The Desecularization of the World," 7.

${ }^{45}$ Ibid., 12.

${ }^{46}$ Samuel Huntington, “The Clash of Civilizations?," Foreign Affairs 72 (1993): 23-49.
} 
in the 1990s which was commonly regarded as religious conflict. But, P.J. O'Rourke's observation reveals that three parties involved in the conflict "are of the same race, speak the same language, and only distinguished by their religion, which none of them believe."

Like it did in the past, religion has also played its role in world peace as well as in war in the modern secular world. ${ }^{48}$ Religious institutions have initiated to establish peace, oppose warlike policies, and become a mediator between parties involved in the conflict. The Vatican was successful in mediating some conflicts in Latin America and Protestant and Catholic clergy, though not successful, were involved as a mediator of the conflict in the Northern Ireland. Yet, it is believed that religious movement and institutions foster war between and within nations. They have played an anchor role in war and civil war in the Israeli-Palestinian conflict, the Indian subcontinent and some countries in Africa.

In addition, religion has been involved in economic development. This is not all new. Max Weber in his 1905 work The Protestant Ethic and the Spirit of Capitalism explained that Protestant ethic, such as hard work, frugality, personal discipline and respect for learning, was a driving force in the development of capitalism and free market in Europe. In the world today, the new Evangelicalism has revived these values of Protestant ethic in its efforts to increase the economic life of people in Latin America. Muslim emigrants in several Western countries and an Islamic movement in Indonesia have exhibited successful efforts in economic development by combining "rigorous theological orthodoxy with a market-friendly openness in economic matters." 49

Religion has also taken its part in the field of human rights and social justice, for example, by making statements concerning human rights and social justice, which some of them had political implications such as in the civil rights movement in the United State and the collapse of Communists government in Europe. Religious institutions or groups have

\footnotetext{
${ }^{47}$ Berger, "The Desecularization of the World," 15.

48 Ibid., 15-16.

${ }^{49}$ Ibid., 16.
} 
expressed their positions, for or against, on matters such as abortion, contraception, homosexuality, and drug abuse..$^{50}$

\section{The Rise of Religious Environmentalism}

New roles of religion in the global society can be seen particularly in the involvement of religious individuals, institutions and groups in environmental problems and ecological issues. Matters like global warming, overpopulation, ozone depletion, habitat destruction, and waste disposal have become a global concern not only of environment activists, but also of religious leaders and elites. This religious environmentalism can be seen, among others, in the statement by Pope John Paul II in 1989, "Peace with God the Creator, Peace with All of Creation," the first papal statement on Catholic church on ecology, and "the elevation of ecological concern to a level comparable with peace and justice on its list of applied religious priorities" by World Councils of Church in its 1999 meeting. ${ }^{51}$

The phenomenon that religious leaders pay attention to ecological issues is not all new. In the 1960s, a few liberal Christian leaders considered environmental problems as important issues and religiously significant. ${ }^{52}$ Various Christian churches made statements and resolutions in their documents and meeting concerning ecological issues. ${ }^{53}$ Nevertheless, environmental issues remained a marginal concern in majority of religious institutions until the latter 1980s. It was only in the 1990s that environmental issues gained wider attention, shifting from the marginal concern to a mainstream concern, in global society including religious institutions, in developed countries as well as in less developed ones. $^{54}$

Global environmental issues, generated by globalization, are considered to point to a religious idea of the whole creation. World Council of Churches, for example, made a theological statement that links

\footnotetext{
${ }^{50}$ Ibid., 17-18.

51 Peter Beyer, Religion and Globalization (London: Sage Publications, 1994), 206.

52 Beyer, Religion and Globalization, 206.

53 Walsh and Davies as cited in Beyer, Religion and Globalization, 206.

${ }^{54}$ Gorrie as cited in Beyer, Religion and Globalization.
} 
environmental degradation and "healthy relationship in creation in whole:"

In the international scene we confront two major problems: (a) the worldwide social justice crisis; and (b) the global ecological and environmental crisis...A new vision will integrate our interdependent ecological, social, economic, political and spiritual needs. We want to say as forcefully as we can that social justice for all people and eco-justice for all creation must go together...Justice is truly invisible, not only as a matter of theological conviction but also in practice. The biblical concept of justice recognizes the need for healthy relationship in creation in a whole. This way of viewing justice helps us understand the linkage between poverty, powerless, social conflict and environmental degradation. ${ }^{55}$

Yet, the upsurge of religious environmentalism is not typical to Christian people and institutions. It also involves religious actors of other religions. In Judaism, for example, mainstream American rabbis have begun to speak against environmental crises from Jewish theological perspectives as well as grassroots Jewish movement have developed leadership program and practical approach to ecological issues. Conferences and consultations on Judaism and ecology have been held, such as one in the USA by the Center for the Study of World Religions at Harvard University, which appear in a 2002 edited volume Judaism and Ecology: Created World and Revealed World. ${ }^{56}$

In Islam, concern of ecological crises can be seen primarily in any attempt by Muslim leaders and scholars to show an inseparable relation between God, nature and humankind from the theological perspectives, namely the Qur'an and Hadis (the prophet Muhammad's saying and practices). ${ }^{57}$ Muslim attention in the threat of ecological crises also can be seen in their involvement in world conferences and symposia on religion and ecology as well as practical solutions.

\footnotetext{
${ }^{55}$ Beyer, Religion and Globalization, 215.

${ }^{56}$ Jane Kay Guelke, "Review," of Judaism and Ecology: Created World and Revealed World, ed. Hava Tirosh-Samuelson, Harvard University Press, Cambridge, Shofar 23, no. 1 (2004): 189.

57 S. Nomanul Haq, "Islam and Ecology: Toward Retrieval and Reconstruction," Daedalus 130, no. 4 (2001): 141.
} 
The rise of religious environmentalism reflects an attempt of religion and religious actors to maintain their existence in the face of globalization. It is one of their efforts to insert or reinsert themselves into public domain and play new roles in accordance with a rapid change of global society. ${ }^{58}$ Put it simply, religious environmentalism can be regarded as an adaptation strategy by religious actors to survive and persist in the global world.

It can be said that religion in the global society cannot directly involved in practical solutions to environmental problems. Religious actors and organizations can only offer ethical principles of sustaining the ecology and living in harmony with nature. Nevertheless, it is not necessarily useless; religion and religious actors can provide ideological and motivational resources for any movements concerned of environmental issues. This maybe a marginal contribution and participation in global issues like environmental degradation, but it can show that religion still exists in the globalizing world, can do something and play a role for the global society.

\section{Formal Religion is in Decline}

The global society has witnessed a massive revival of religion in many parts of the globe. However, secularization theory seems to hold in two exceptions. ${ }^{59}$ First, Western Europe can be the best evidence of secularization theory. The increasing modernization in this region has resulted in the increasing indicators of secularization both in the level of personal religiosity and, more dramatically, in the level of religious institutions such as church attendance, church-directed behavior and church personnel recruitment. Italy, Spain and Greece have seen a sharp decline of "church-related religion" or institutionalized religion. Only 11 percent of population in France and Czech Republic consider religion as very important in their lives. ${ }^{60}$ As Berger predicts, Eastern Europe will

\footnotetext{
58 Beyer, Religion and Globalization, 207.

59 Berger, "The Desecularization of the World," 9-10.

${ }^{60}$ Cahill, "God and Globalization," 2.
} 
experience the similar development as countries of this region will be integrated, some have, into the European Union. ${ }^{61}$

A survey of religious attitude in 1999 by the Gallup Millennium Survey reveals that the proportion of people who never go to church is 48 percent of Western Europe population. Of ten of population, less than one goes to church at least once a month in Britain, Germany, the Netherlands, Sweden and Denmark. Regarding belief in God, the survey shows that 49 percent of Danes, 52 percent of Norwegians and 55 percent of Swedes consider the irrelevance of God in their lives. The proportion of Czech population who hold this view constitute the highest level, nearly two-third of population. This trend of "de-Christianization of Europe", as Fergusson calls, also holds true for Eastern Europe, despite it is lower slightly than Western Europe; the Gallup survey indicates that 44 percent of people living in this region never go to church. ${ }^{62}$

Statistical data show that, in Britain, proportion of people going to church has been declining since the 1851 Census of Religious Worship..$^{63}$ Among adult population of England and Wales in the mid-19 $9^{\text {th }}$ century, more than half went to church every Sunday. But, by the end of the $20^{\text {th }}$ century, the number of churchgoers was in decline, to less than one-twelfth of population. ${ }^{64}$ The last four decades also witness the same trend in terms of church attendance ${ }^{65}$ as well as religious belief. ${ }^{66}$

British Household Panel Survey shows a general trend of religious attendance and affiliation in Britain: each successive generation is less religious than previous one, not only among younger generations but also among the elder groups. ${ }^{67}$ As Crockett and Voas conclude, religious decline in $20^{\text {th }}$ century Britain occurs in every generation, in which "each

\footnotetext{
${ }^{61}$ Berger, "The Desecularization of the World," 10.

62 As cited in Niall Fergusson, "Economics, Religion and the Decline of Europe," Institute of Economic Affairs, 2004, 38.

63 Alasdair Crockett \& David Voas, "Generations of Decline: Religious Change on $20^{\text {th }}$ Century Britain," Journal of the Scientific Study of Religion 45, no. 4 (2006): 567.

${ }^{64}$ As cited in Crockett and Voas, "Generations of Decline," 567.

${ }^{65}$ Brown and Bruce as cited in Crockett and Voas, "Generations of Decline."

${ }^{66}$ Gill et al. as cited in Crockett and Voas, "Generations of Decline."

${ }^{67}$ Crockett and Voas, "Generations of Decline," 570, 572.
} 
birth cohort is less religious than the one before." This trend is predicted to continue into the $21^{\text {st }}$ century. ${ }^{68}$

However, decline in religious observance and affiliation does not necessarily mean decline in religious beliefs in personal lives. In her 1994 book, Religion in Britain since 1945: Believing without Belonging, Davie found that people, particularly in Britain, believe in the sacred and religious beliefs in their personal lives though their formal affiliation to religious institutions and religious attendance are undeniably declining. She calls this religious trend in contemporary society "believing without belonging." ${ }^{69}$

In addition, the growing number of immigrant population in Western Europe can be a counterforce to the rate of religious decline. Immigrants, most of them non-Christians, are regarded as to be far more religious than host population. This is true not only for older generations, but also for the younger and those born in host countries. ${ }^{70}$ These immigrants, mostly non-white, are more than three times as likely as their white countrymen to attend religious services. The decrease of religious attendance among the host population and the increase of the number of immigrants in turn result in the increase of percentage of immigrants who attend religious services, rising from less than 7 percent in 1983/1984 to 17 percent in $2001 / 2002 .{ }^{71}$ This trend would eventually be a counterforce to religious decline and bring about the persistence and revival of religion in Western Europe.

The recent data of church attendance cannot lead us to conclude that religion is coming to an end in Europe. Rather, in the words of Andrew Greely, "religion in Europe, like most other human phenomena, is gray. It has declined in some countries, has increased in other countries,

\footnotetext{
${ }^{68}$ Ibid., 581.

${ }^{69}$ Stark, "Secularization R.I.P."; David Kettle, "Believing without Belonging? Cultural Change Seen in Theological Context," International Review of Mission 94, no. 375 (October 2005), 507-509.

70 Crockett and Voas, "Generations of Decline," 579.

${ }^{71}$ Crockett and Voas, "Generations of Decline," 579.
} 
remains high and stable in yet other countries, stable and diffuse in still countries, and stable and low in yet other countries." ${ }^{, 72}$

In addition to Europe, the exception to desecularization of the world, according to Berger, is an "international subculture" which consists of people, mostly intellectuals, who are educated, particularly in social science and humanities, in Western-style higher education. ${ }^{73}$ This subculture is secularized, progressive, and holds enlightened beliefs and values. The members of this subculture hold influential positions in their country such as in educational institutions, mass media and legal system. However, as Berger says, it is not clear why this globalized elite culture is "so prone to secularization." "This subculture seems have not yet been elaborated. A further examination of this elite subculture is needed to answer this question.

\section{Conclusion}

It is safe to say that consequences of globalization on contemporary society are not homogeneous. Globalization, in fact, has diverse implications on various aspects of global society. Following this argument, the globalization process has affected religion in different ways. Religion has proven persistent in the face of globalization. This does not mean that religion is not affected by a rapid flow of globalization. Religion has changed by adapting to new circumstances and developing new roles and identities for itself. Moreover, religion has experienced a resurgence world widely in the form of fundamentalist movements that appear in major world religion as well local and national religions. They are a reaction to powerful force of globalization. In the words of Ahmad, "when there is power, there is also resistance.", 75

\footnotetext{
${ }^{72}$ Andrew M. Greely, "Religious Decline in Europe?," America Magazine, March 1, 2004, 16.

${ }^{73}$ Berger, "The Desecularization of the World," 10-11.

${ }^{74}$ Ibid., 10.

75 Mahmood Ahmad, "Religious Resurgence in an Era of Globalization: Islam's Quest for Global Participation,” Globalization 5, no. 2 (2005).
} 
The worldwide resurgence of religion has falsified secularization theory; experiment with the end of religion in secular global society has failed and religious beliefs and practices have to some degree succeeded. Prophecies of the death of religion as echoed by proponents of secularization thesis are not accomplished. It can be said here the conviction of the end of religion in secular global society has become a myth of secularization theory. ${ }^{76}$ It is a fact that contemporary globalizing society has experienced what Berger called "desecularization of the world."

Globalization has also implied on religion in another consequence. Problems and challenges resulted from globalization, such as secularized society and ecological crises, will provide religion with chances and power to revitalize itself and transform itself into a new form with new roles and identities. The consequences of globalization on contemporary society have pointed to a different direction; they have resulted in the rise of religion with new roles and identities in the global order as reflected in religious environmentalism. From the perspective of "revitalization movement" by Anthony Wallace, as globalization problems deepen, historical precedent suggests that religious shifts in affected cultures may follow." 78 Thus, globalization has helped religion to transform itself and change strategies in coping with problems and challenges offered by globalization.

The last state of religion in the globalizing world is that religion has gone into a decline as seen in the religious attitudes among people living in Europe and certain intellectual subculture. Statistical data show that the proportion of people who observe religious teaching and morality has fell dramatically in this region decade by decade, year by year and generation by generation since the beginning of the $20^{\text {th }}$ century. However, the religious existence in Europe cannot be summarized in one category. Religion is gray in this continent as the data also indicate religion persists in the personal lives of people. Religious decline in public sphere does not

\footnotetext{
76 Stark, "Secularization, R.I.P."

77 Berger, "The Desecularization of the World."

78 Matthew Orr, "Environmental Decline and the Rise of Religion," Zygon 38, no. 4 (2003): 895-910.
} 
mean necessarily the death of religion in the private lives of European people as there exists what so called "believing without belonging" and a counterforce to the decline from immigrants who show much higher level of religious observance than the host population. Thus, it is safe to say that religion is not, and would not be, a declining force in the globalizing world, at least in private sphere, for religion is able to transform itself into a new form with new roles and identities as crises deepen and participate, or even shape, in the globalization process.

\section{Bibliography}

Ahmad, Mahmood. "Religious Resurgence in an Era of Globalization: Islam's Quest for Global Participation." Globalization 5, no. 2 (2005).

An-Na'im, Abdullahi A. "Political Islam in National Politics and International Relations." In The Desecularization of the World: Resurgent Religion and World Politics, ed. Peter L. Berger, 103-122. Washington: Ethics and Public Policy Center, 1999.

Berger, Peter L. "The Desecularization of the World: A Global Overview." In The Desecularization of the World: Resurgent Religion and World Politics, ed. Peter L. Berger, 1-18. Washington: Ethics and Public Policy Center, 1999.

Beyer, Peter. Religion and Globalization. London: Sage Publications, 1994.

Cahill, Desmond. "God and Globalization: the Role of Faith Communities in Building Social Capital and Constructing Peace." Paper prepared for the conference International Perspectives on Peace and Reconciliation, the University of Melbourne, July 2003.

Crockett, Alasdair \& Voas, David. "Generations of Decline: Religious Change on $20^{\text {th }}$ Century Britain." Journal of the Scientific Study of Religion 45, no. 4 (2006): 567-584.

Fergusson, Niall. "Economics, Religion and the Decline of Europe." Institute of Economic Affairs (December, 2004): 37-40. 
Fox, Jonathan. "Religion as an Overlooked Element of International Relations." International Studies Review 3, no. 3 (2001): 53-73.

Greely, Andrew M. "Religious Decline in Europe?." America Magazine, March 1, 2004, 16-18.

Guelke, Jane Kay. "Review" of Judaism and Ecology: Created World and Revealed World, ed. Hava Tirosh-Samuelson, Harvard University Press, Cambridge, Shofar 23, no. 1 (2004): 189-191.

Hall, Stuart. "The Question of Cultural Identity." In Modernity, An Introduction to Modern Societies, eds. Stuart Hall and David Held, 595634. Malden: Blackwell Publishing, 2000.

Haq, S. Nomanul. "Islam and Ecology: Toward Retrieval and Reconstruction." Daedalus 130. no. 4 (Fall, 2001): 141.

Hefner, Robert. "Multiple Modernities: Christianity, Islam and Hinduism in a Globalizing Age." Annual Review of Anthropology 27 (1998): 83104.

Huntington, Samuel. "The Clash of Civilizations?." Foreign Affairs 72 (1993): 23-49.

Kettle, David. "Believing without Belonging? Cultural Change Seen in Theological Context." International Review of Mission 94, no. 375 (October, 2005): 507-509.

Martin, David. "The Evangelical Upsurge and Its Political Implications." In The Desecularization of the World: Resurgent Religion and World Politics, ed. Peter L. Berger, 37-50. Washington: Ethics and Public Policy Center, 1999.

McGrew, Anthony. "A Global Society?." In Modernity, An Introduction to Modern Societies, eds. Stuart Hall and David Held, 466-503. Malden: Blackwell Publishing, 2000.

Orr, Matthew. "Environmental Decline and the Rise of Religion." Zygon 38, no. 4 (2003): 895-910.

Riesebrodt, Martin. "Fundamentalism and the Resurgence of Religion." Numen 47, no. 3 (2000): 266-287. 
Sack, Jonathan. "Judaism and Politics in the Modern World." In The Desecularization of the World: Resurgent Religion and World Politics, ed. Peter L. Berger, 51-64. Washington: Ethics and Public Policy Center, 1999.

Sasaki, Masamichi. "Globalization and National Identity in Japan." International Journal of Japanese Sociology 13, no. 1 (2004): 69-87.

Stark, Rodney, “Secularization, R.I.P." Sociology of Religion 60, no. 3 (1999): 249-273. 